\title{
Nie-egte vrae in 1 Korintiërs 9
}

\begin{abstract}
Non-real questions in 1 Corinthians 9

In 1 Corinthians 9 Paul is defending his apostleship in a forceful way. In this process he uses a number of non-real questions, which commentators usually describe as rhetorical questions. The purpose of this article is to analyse and describe these questions more clearly using a model, based on speech act theory. The model distinguishes between real and non-real questions, the latter being divided into six main and a few sub-categories of non-real questions. Four of these categories are identified in 1 Corinthians 9.

The conclusion reached is that the denominator "rhetorical question" is an oversimplification that does not do justice to the various types of questions used in the chapter. By distinguishing and describing the types of questions within a scientific framework, more light is shed on the way in which Paul uses them to convince his audience of his apostleship. The article also contributes to the translation and exegesis of this important chapter in the letter.
\end{abstract}

\section{INLEIDING}

Hoewel vraagvorme in die meeste Griekse grammatikas bespreek word, is hierdie vraagvorme tot onlangs nog nie sistematies ondersoek en beskryf in terme van 'n moderne taalteoretiese raamwerk nie. In aansluiting hierby word alle vrae in die Nuwe Testament deur kommentatore gewoonweg as retoriese vrae beskou, sonder om tussen die soorte vrae te onderskei of die vrae se funksies binne ' $n$ teoretiese raamwerk te probeer verstaan.

Die doel van die artikel is om bogenoemde tekorte aan te spreek deur gebruik te maak van 'n model gebaseer op die taalhandelingsteorie. In wat volg, word begin met ' $n$ illustrasie van die probleem deur ' $n$ kort bespreking van die wyse waarop vrae in tradisionele grammatikas en kommentare hanteer word, waarna die voorgestelde model beskryf en geëvalueer word. Die model word vervolgens toegepas op 1 Korintiërs 9 om aan te toon hoe Paulus verskillende soorte vrae gebruik in die verdediging van sy apostelskap. So word die funksies van die vrae wetenskaplik bepaal en word aangetoon hoe die vrae wat Paulus gebruik bydra om die ontvangers van sy boodskap te oorreed.

\section{VRAE IN TRADISIONELE GRAMMATIKAS EN KOMMENTARE}

'n Tipiese voorbeeld van die wyse waarop Griekse grammatikas vrae bespreek, is die werke van Moulton en Turner. In sy eerste volume het Moulton (1908:170-194) dit veral oor die onderskeiding tussen mē/mēti en ou vrae, terwyl Turner (1963:48-50; 282-283 en 330-337) onderskei tussen direkte en indirekte vrae en aandag gee aan formele sake soos die verwarring

1 Prof AH Snyman, Fakulteit Teologie, Universiteit van die Vrystaat, Posbus 339, Bloemfontein 9300.

E-pos: asnyman44@gmail.com Selfoon: 0742153070 
tussen relatiewe en vraende voornaamwoorde, die beraadslagende vraag, partikels wat vraagvorme inlei en die gebruik van direkte vraende voornaamwoorde.

Soortgelyke sake is aan die orde in die meeste ander grammatikas, byvoorbeeld die van Robertsen (1919:1043-1046; 1175-1177), Chamberlain (1957:204-210), Goetchius (1965:228233), Argyle (1965:20, 105-106) en Nunn (1973:82, 127). Burton (1955:76-78) onderskei tussen "questions of fact and questions of deliberation", en tussen "interrogative or real questions and rhetorical questions", terwyl die grammatika van Blass, Debrunner en Funk (1967:272) vier tipes vrae onderskei: direkte vrae, indirekte vrae, retoriese vrae en dubbele vrae. Veral laasgenoemde twee grammatikas is vir die doel van hierdie artikel belangrik en daar word later na hulle onderskeidinge teruggekom.

In die eerste Afrikaanse grammatika van die Griekse Nuwe Testament (NT), getitel Grieks met begrip, word vraagsinne behandel onder die hoofde informatiewe vrae, nie-informatiewe of retoriese vrae, vraagsinne ingelei deur vraende voornaamwoorde en indirekte vrae (Conradie et. al. 1995:415-420). Die onderskeiding tussen informatiewe en nie-informatiewe of retoriese vrae bevat 'n interessante bespreking van vrae waarop die antwoord "ja" en dié waarop die antwoord "nee" verwag word, met bruikbare voorstelle vir die vertaling daarvan in Afrikaans.

Standaard kommentare op 1 Korintiërs soos dié van Conzelmann (1975), Fee (1988) en Thiselton (2000) beskou alle vrae as retoriese vrae. Conzelmann bespreek hierdie vrae as deel van Paulus se diatribe/dialogiese styl, Fee gee veral aandag aan die funksies van vrae om 'n argument te begin of af te sluit, terwyl Thiselton die vertaling van $m e \bar{e} / o u$ vrae en die gevoelswaarde van retoriese vrae uitlig. Bratcher (1982) fokus op vertaling en is ten gunste van die herskryf van die meeste retoriese vrae in 1 Korintiërs 9 as stellings - iets wat oorweging verdien en ook hieronder bespreek word.

Saamgevat: Tradisionele grammatikas onderskei basies tussen informatiewe en nieformatiewe vrae (met enkele opmerkings oor die funksies van laasgenoemde), terwyl kommentare hoofsaaklik die retoriese vraag ken en sporadiese opmerkings daaroor maak.

Hiermee is die verskillende vraagvorme met hulle funksies egter nie uitgeput of aan die hand van 'n teoretiese raamwerk sistematies ondersoek nie. In wat volg word ' $n$ poging aangewend om dit te doen aan die hand van die vrae in 1 Korintiërs 9 . In die proses word verwys na die interpretasie en vertaling van vrae deur kommentatore en vertalers en word (waar nodig) aanbevelings gemaak.

\section{DIE TAALHANDELINGSTEORIE AS RAAMWERK VIR DIE ONDERSKEIDING VAN VERSKILLENDE SOORTE VRAE}

In sy studie van nie-egte vrae in die Romeinebrief het Verster (1999:1) ook gevind dat kommentatore die meeste vrae in die brief as retoriese vrae beskou. Hierdie bevinding het daartoe gelei dat hy begin vra het na 'n teorie wat fyner onderskeiding moontlik maak. Die doel van sy studie was om 'n model uit relevante literatuur oor die taalhandelingsteorie af te lei, nieegte vrae aan die hand daarvan in te deel, die model in die Romeinebrief te toets, en dit dan - indien nodig - aan te pas (1999:1-2).

Verster se ondersoek begin met die grondslae van die taalhandelingsteorie (1999:3-28). Hierna bied hy ' $n$ deeglike bespreking van nie-egte vrae as taalhandelinge (1999:29-54), waarna hy eers egte en nie-egte vrae van mekaar onderskei en dan 'n aantal kategorieë nie-egte vrae identifiseer. By egte vrae maak die mededeler (M) gebruik van die vraagvorm om inligting te bekom, terwyl nie-egte vrae nie inligting of 'n antwoord van die ontvanger (O) verlang nie. Elke kategorie nie-egte vrae is voorsien van ' $n$ aantal kriteria op grond waarvan dit van die ander onderskei kan word (1999:55). 
Die kategorieë nie-egte vrae is die volgende (1999:56-68):

- Vrae wat aksie verlang, waaronder direktiewe, wat die vraagvorm gebruik vir opdragte, versoeke en uitnodigings.

- Vrae wat stellings maak, waar die vraagvorm as 'n gewone stelling herskryf kan word gewoonlik nie met absolute sekerheid nie; retoriese vrae, wat stellings met besondere intensiteit maak; en meta-kommunikatiewe retoriese interrogatiewe, waar $\mathrm{M}$ gevolgtrekkings maak oor ' $n$ aksie wat deur $O$ geneem is.

- Leë vraagstellings, waar M reageer op 'n taalhandeling van $O$ en 'n negatiewe stelling maak, waardeur die gesprek onderbreek word.

- Vrae wat emosie oordra, waaronder jubelvrae en lamentasies. Ook hier word geen inligting verlang nie, maar word die vraagvorm gebruik om 'n bepaalde emosie te versterk of uit te druk. Dit is vraagvorme waar 'n eksterne $\mathrm{O}$ afwesig kan wees.

- Monologiese selfgerigte vrae, wat van ander nie-egte vrae daarin onderskei word dat hulle besinnend van aard is en gewoonlik aan M self ("ek" of "ons") gerig is. Hulle kan primêr emosioneel of primêr rasioneel wees.

- Rasioneel-argumentatiewe vrae, waaronder vraagappélle, wat nie 'n reaksie van O verwag nie, maar sy/haar aandag wil kry vir 'n nuwe tema of 'n stelling wat M self wil maak; en ironiese retoriese interrogatiewe, waar die betekenis van die nie-egte vraag nie lê in die oppervlak nie, maar in die teenoorgestelde van wat deur die vraag geïmpliseer word. Die vraag moet uit die konteks verstaan word as ' $n$ ironiese toespeling. Vraagappélle en ironiese vrae dien albei om ' $n$ argument te ontwikkel - daarom is hulle onder hierdie hoofkategorie ingedeel.

Om bogenoemde soorte vrae te onderskei, is die onmiddellike konteks waarin hulle voorkom, maar veral die konteks van die brief as geheel, van deurslaggewende belang. In die taalhandelingsteorie word na laasgenoemde verwys as Gedeelde Kontekstuele Kennis (GKK), verwysend na kennis van sosiale sisteme, tradisionele gewoontes, spesifieke gespreksituasies en veral die verhouding tussen spreker en hoorder (Verster 1999:70-71). Die vier aspekte word gewoonlik toegelig deur 'n bespreking van die skrywer, lesers, inhoud en doel van 'n brief; dus alles wat nodig is om die soorte vrae in die brief korrek van mekaar te onderskei.

Met bogenoemde voorstel het Verster dit moontlik gemaak om nie-egte vrae in die NT te bestudeer in die lig van onderskeidinge eie aan 'n erkende taalteorie. Die hoof- en subkategorieë wat hy onderskei, kan egter vereenvoudig word. Naas die ses hoofkategorieë hierbo gelys, onderskei hy ook 'n sewende een, te wete temaversterkers. Hierdie kategorie word nie in die artikel verreken nie, omdat temaversterkers (soos vraagappélle) aandag vra vir 'n nuwe tema of stelling wat $\mathrm{M}$ wil maak. Die vrae kan dus as vraagappélle geklassifiseer word. Verder kan die term "retories" geskrap word in die beskrywing van die twee subkategorieë metakommunikatiewe retoriese interrogatiewe en ironiese retoriese interrogatiewe, omdat daar reeds 'n subkategorie retoriese vrae is. Verder kan die hoofkategorie van vrae wat emosie oordra verdeel word in positiewe emosies (soos dankbaarheid, blydskap, ens.) en negatiewe emosies (soos afsku, teleurstelling en verontwaardiging), omdat die terme jubelvrae en lamentasies nie oorkoepelend genoeg is nie. Origens is dit ' $n$ bruikbare model, wat met vrug in die studie van vrae in Paulus se briewe gebruik kan word.

Vervolgens word bogenoemde model gebruik om die verskillende soorte vrae in 1 Korintiërs 9 te identifiseer en hulle funksies binne konteks te bepaal.

\section{NIE-EGTE VRAE EN HULLE FUNKSIES IN 1 KORINTIËRS 9}

\subsection{Inleiding}


Die volgende inligting oor die GKK tussen Paulus en die Korintiërs is belangrik vir ' $\mathrm{n}$ bespreking van die soorte nie-egte vrae in 1 Korintiërs 9:

Daar was aanvanklik 'n goeie verhouding tussen die twee partye, soos blyk uit die feit dat Paulus die gemeente in Korinte gestig het (Hand 18). Die verhouding is versterk deur berigte wat hy gereeld van die gemeente ontvang het. In die brief reageer hy juis op ván die inligting wat hom bereik het. Die eerste handel oor twiste in die gemeente, waaroor "die mense van Chloë" hom ingelig het (1:11). Hierdie mense was in diens van 'n invloedryke sakevrou in Efese en het Korinte gereeld op hulle reise besoek, waar hulle saam met die Korintiërs aanbid het (Thiselton 2000:32). Die twiste was hoofsaaklik intern van aard en het uitgeloop op partyskappe tussen die gemeentelede onderling. Paulus se reaksie op die twiste is die sentrale tema in die eerste ses hoofstukke van die brief.

Die verhouding tussen Paulus en die Korintiërs is verder versterk deur ' $n$ brief wat hulle aan hom geskryf het (7:1). In die brief vra hulle sy leiding oor 'n aantal - hoofsaaklik etiese kwessies. Sekere Christene in Korinte het ook gevra vir 'n besoek van Apollos, maar hy wou nie op daardie stadium gaan nie (16:12). Paulus het aangebied om self te gaan $(4: 19,21)$, maar aangesien sy planne onseker was, het hy vir Timoteus in sy plek gestuur (4:17; 16:10). Die besoek van Stefanas, Fortunatus en Agaïkus, waarna in 16:17-18 verwys word, dui ook op die noue sosiale verbintenis tussen Paulus en die gelowiges in Korinte.

Toe die brief geskryf is, het die verhouding tussen Paulus en die Korintiërs egter begin versleg. Daar het 'n anti-Paulus gevoel in die gemeente ontstaan, wat aangestig is deur sekere invloedryke leiers en wat die hele gemeente beïnvloed het. Benewens die interne twiste tussen faksies binne die gemeente - waarskynlik op sosiologiese gronde - was daar dus ook die groter probleem van die verdeling van die gemeente as geheel aan die een kant en Paulus as hulle stigter aan die ander kant (Fee 1988:8). Vir Paulus het hierdie groter konflik 'n krisis ingehou: nie alleen vir sy apostoliese gesag nie, maar ook vir die evangelie wat hy verkondig. Die kern van die verskil was wat dit beteken om Geesvervuld of spiritueel (pneumatikos) te wees en die belangrikste kriterium hiervan was die spreek in tale. Omdat Paulus (volgens hulle) nie pneumatikos was nie, het hulle sy gesag oor hulle begin bevraagteken en hulleself begin verhef - iets wat radikaal ingedruis het teen Paulus se oortuigings en sy evangelie. Gevolglik het hy sy apostoliese gesag verdedig, soos o.a. blyk uit sy bestraffings in hoofstukke 5-6 (Thiselton 2000:33-36; Grosheide 1957:26-31).

Seker die sterkste verdediging van sy gesag is te vind in hoofstuk 9, wat deel vorm van sy antwoord op die brief wat hulle aan hom geskryf het (7:1). In die hoofstuk verdedig hy homself "teen dié wat regter oor my speel" (vers 3). Die tema van die hoofstuk is die regte en vryheid van 'n apostel en in sy verdediging roer hy ook die kwessie van handearbeid aan: al kan hy van die reg op hulle onderhoud gebruik maak, het hy dit nie gedoen nie, maar met sy hande gewerk om homself te onderhou (9:3-14). Dit was, volgens die Korintiërs se siening, vernederend vir 'n wyse man (sophos) om dit te doen. In die hoofstuk verdedig Paulus sy optrede en handhaaf hy sy gesag as apostel.

Wat was die oorsaak van die Korintiërs se valse spiritualiteit? Fee (1988:13-15) bespreek verskillende moontlikhede, en sluit dan aan by Gerd Theissen wat argumenteer dat die spanning binne die gemeente, asook die spanning tussen die gemeente en Paulus, die beste verklaar kan word in terme van sosiologiese verskille. Aangesien die rykes as beskermhere van gemeentes en rondreisende leermeesters opgetree het, het die strydende faksies bestaan uit verskillende beskermhere met hulle huisgemeentes. Hierdie beskermhere was moontlik die leiers van die anti-Paulus gevoel in Korinte, soos blyk uit hulle voorliefde vir sophia, uit die feit dat hy hulle nie as beskermhere wou aanvaar nie (9:1-19) en uit hulle optrede teenoor die armes by die nagmaal (hoofstuk 10).

Die verdediging van sy gesag as apostel baken hoofstuk 9 af as 'n eenheid vir ondersoek. In 
hierdie hoofstuk gebruik Paulus verskillende vrae as deel van sy oorredingstrategie. Die hoofdoel van hierdie studie is om die soorte vrae wat Paulus stel te identifiseer en te bespreek binne ' $n$ taalteoretiese raamwerk. Hierop word nou ingegaan.

\subsection{Nie-egte vrae in 1 Kor 9}

Daar is nie 'n voorbeeld van 'n egte vraag wat inligting verlang, in hoofstuk 9 gevind nie. Van die kategorieë nie-egte vrae hierbo onderskei, is die volgende egter wel gevind:

\subsubsection{Vrae wat as stellings beskou kan word}

Voorbeelde van twee van die drie kategorieë waarin hierdie hoofkategorie uiteenval, kom in hoofstuk 9 voor: vraagvorme wat gewone stellings maak en metakommunikatiewe interrogatiewe. Die ooreenkoms tussen hierdie twee soorte nie-egte vrae is dat albei stellings maak, alhoewel hulle onderling verskil.

\subsubsection{Vraagvorme wat gewone stellings maak}

Die kenmerkende van die kategorie is dat die vraagvorm gewoonlik herskryf kan word as ' $n$ stelling. Hierdie is vraagvorme wat in Grieks gemerk is met die partikel ou (wat 'n positiewe antwoord verwag), of $m \bar{e}$ (wat 'n negatiewe antwoord impliseer). Volgens Conradie (1995:416) word eersgenoemde goed weergegee deur dit te negativeer en woorde soos "dan" of "mos" toe te voeg, terwyl vrae met 'n negatiewe implikasie versterk kan word met "mos nie" of "tog seker nie".

Wat hierdie kategorie nie-egte vrae betref is dit telkens onseker of ' $n$ vraagvorm as ' $n$ vraag of ' $n$ stelling vertaal moet word. Die probleem word veroorsaak deur die feit dat ons slegs ' $n$ geskrewe teks voor ons het. In gesproke taal is die probleem nie so groot nie, omdat die intonasie van die spreektaal ons help om 'n sinsvorm - met die fatiese struktuur van 'n stelling - as 'n vraag te verstaan. Vergelyk byvoorbeeld:

"Jy weet nie?"

met

"Jy weet nie". (Van Jaarsveld 1987:292).

In gesproke taal hoef hier geen onduidelikheid te wees nie. In geskrewe taal kan slegs die konteks en die gang van die argument ons help om tot 'n mate van duidelikheid te kom; slegs tot 'n mate, omdat ons nooit absoluut seker kan wees nie. Dit lê op die weg van die vertaler om die leser hiermee te help. Dit geld veral vir vrae, wat in Grieks deur ou of $m \bar{e}$ gemerk is en dus duidelike positiewe of negatiewe antwoorde impliseer.

Met vraagvorme wat gewone stellings maak, wil M nie die gesprek onderbreek nie, maar wil hy inligting op so ' $n$ wyse kommunikeer dat O duidelik moet verstaan wat hy sê. Uit die konteks is dit duidelik dat $\mathrm{M}$ nie ' $\mathrm{n}$ antwoord verwag nie; hy wil net sy argument versterk en verder voer. En omdat $M$ nie 'n antwoord verwag nie, is die voorbeelde wat volg tipiese nie-egte vrae.

1 Kor 9:4: Het ons dan nie reg op lewensonderhoud nie?

9:5: Het ons nie selfs die reg om elkeen sy vrou wat' $n$ gelowige is, op reis saam te neem soos ook die ander apostels en die Here se broers en Sefas nie?

9:6: Of is dit net ek en Barnabas wat nie die reg het om op te hou met die handearbeid vir eie onderhoud nie?

9:7: Wie dien ooit op eie koste as soldaat?

Wie plant 'n wingerd en eet nie van sy vrugte nie?

Of wie pas vee op en geniet nie van hulle melk nie?

Hierdie arsenaal vraagvorme is deel van Paulus se "verdediging teen dié wat regter oor my speel" (9:3) en is almal juridies ingeklee (Lenski 1963:352). In die verse word sy vryheid as apostel, waarna in 9:1 verwys is, nader gedefinieer in terme van sekere regte. Die vrae handel basies 
oor sy reg (eksousia) om gebruik te maak van die Korintiërs se materiële ondersteuning in die uitvoering van sy taak. Die argument in 9:4-7 is 'n argument kata anthrõpon (volgens die mens) en kan in twee verdeel word: 9:4-6 handel oor bogenoemde basiese reg van ' $n$ apostel, terwyl 9:7 dit verder voer aan die hand van sekere voorbeelde. Die voorbeelde vorm ' $n$ integrale deel van die hele rasionele (kata anthrõpon) argument en is nie bloot illustratief nie (Conzelmann 1975:154; Thiselton 2000:683).

Wat verse 4-6 betref: Die twee vraagvorme in verse 4 en 5 is in Grieks gemerk met die twee partikels mē ouk, wat volgens Blass, Debrunner en Funk (1967: par. 427,2) positiewe antwoorde impliseer: Paulus en die ander apostels hét die reg op lewensonderhoud en hy hét (soos die ander) ook die reg om 'n vrou met hom saam te neem op sy reise. Die antwoord op 9:6 is egter negatief, al is dit nie so gemerk nie: nie net Paulus en Barnabas nie, maar alle apostels het die reg om op te hou met handearbeid in diens van die evangelie. Hierdie verskillende antwoorde is egter nie so duidelik uit die Afrikaanse Vertaling van 1983 soos wat dit hierbo aangehaal word nie. Om dit reg te stel, is daar twee moontlikhede:

1. Die eerste moontlikheid is om iets by te voeg in die vertaling, wat die regte antwoorde sal ontlok. Lenski (1963:355-7) skei die twee partikels en argumenteer dat $m \bar{e}$ 'n negatiewe antwoord verwag, terwyl ou net die werkwoord negativeer. Om dit te bereik, begin hy elke vers met: "Do you intend to say that...?", met die implikasie: "You Corinthians do not want to say anything like that". En dan volg die positiewe stelling: "We do have the right to...". Fee (1988:402) skei ook die twee partikels om die probleem op te los en toon aan dat $m \bar{e}^{-}$'n negatiewe antwoord impliseer op 'n sin wat negatief (met ou) geformuleer is. Sy letterlike vertaling van 9:4 lees: "Can it be that we do not have the right to food and drink?" Volgens hom moet hierdie omweg, wat "intensely rhetorical" is, dan tot 'n positiewe antwoord lei. In sy vertaling volg hy egter die gewone: “Don't we have the right to food and drink?" (1988:397).

2. Die tweede moontlikheid is om die vraagvorme as stellings te vertaal. Hierdie moontlikheid word gekies deur Bratcher (1982:80-81), wat ' $n$ voorkeur het om sg. "rhetorical questions" as stellings te vertaal. Hy vertaal die drie verse soos volg: "9:4. I have the right to be given (or, to receive) food and drink for my work as an apostle. 9:5. I also have the right to take a Christian wife with me on my travels, just as the other apostles and the Lord's brothers and Peter do. 9:6. Barnabas and I are not the only apostles who have to work for our living (or, work to support ourselves)".

Watter moontlikheid is die beste? Na my mening die tweede, en wel om die volgende redes. Eerstens is daar geen versekering dat die lesers die implikasies van die vraagvorme reg sal verstaan as daar frases bygevoeg word nie. Die saak word bemoeilik deur die feit dat die implikasies van verse 4-5 aan die een kant, en vers 6 aan die ander kant, verskil: eersgenoemde twee vraagvorme het positiewe implikasies, terwyl vers 6 'n negatiewe antwoord verwag. Of $m \bar{e}$ ou dus saamgelees word as 'n eenheid wat 'n positiewe antwoord impliseer (Blass, Debrunner \& Funk) en of die twee partikels geskei word (Lenski en Fee) maak nie werklik ' $n$ verskil nie; dit blyk die beste te wees om die vraagvorme as stellings te vertaal en so alle onduidelikheid uit te skakel. Tweedens is daar ruimte binne die taalhandelingsteorie om vraagvorme as gewone stellings te herskryf en so hulle betekenis op 'n ondubbelsinnige wyse te kommunikeer.

Word bogenoemde voorstel as oplossing aanvaar, kan 9:4-6 soos volg vertaal word: "9:4. Ons hét mos die reg op lewensonderhoud. 9:5. Ons hét mos die reg om elkeen sy gelowige vrou saam te neem op reis, soos ook die ander apostels en die broers van die Here en Sefas doen. 9:6. Dit is tog nie net ek en Barnabas wat die reg het om op te hou werk (vir ons eie onderhoud) nie".

Wat vers 7 betref: In die vers sit Paulus sy verdediging voort by wyse van 'n aantal voorbeelde, wat bogenoemde stellings bevestig. Die antwoorde op die vrae is vanselfsprekend negatief, al 
is die vrae nie in die Grieks gemerk nie. Hierdie vraagvorme hoef nie as stellings vertaal te word nie, maar kan as vrae behou word. Die drie voorbeelde verwys na heel-verskillende beroepe, t.w. soldaat, landbouer en veeboer, en bewys oortuigend dat apostels ten volle geregtig is op die materiële ondersteuning van diegene wat hulle bedien. Dit sou dus indruis teen die argument kata anthrõpon as iemand vir Paulus (en die ander apostels) hierdie reg om van sy (hulle) arbeid te lewe, sou ontsê.

Al die belangrikste vertalings en kommentare het laasgenoemde drie vrae as vrae vertaal. Hierdie vrae hoort onder die hoofkategorie vraagstellings, waar die vraagvorm behou word om 'n gewone stelling te maak.

\subsubsection{Metakommunikatiewe interrogatiewe}

Soos in die geval van vraagstellings kan vraagvorme in dié subkategorie ook herskryf word as stellings. As tipiese nie-egte vrae word hulle nie gebruik om inligting te bekom nie, maar om inligting te verskaf. In die geval van die soort nie-egte vrae maak M 'n gevolgtrekking oor ' $n$ argument wat gevoer of 'n aksie wat deur $O$ geneem is. Deur die gevolgtrekking wat gemaak word, word die argument prakties toegepas (Verster 1999:97-100).

Twee voorbeelde van die soort vraagvorm kom in hoofstuk 9 voor:

1 Kor 9:11-12: As ons vir julle die geestelike saad gesaai het, is dit dan te veel gevra as ons van julle die stoflike lewensonderhoud sou inoes? As julle aan ander hierdie reg toestaan, kom dit ons dan nie nog meer toe nie?

Met die twee vraagvorme vat Paulus sy argument in 9:4-10 saam. In die gedeelte het hy verskeie redes aangevoer waarom hy, op grond van sy apostelskap, reg het op die Korintiërs se materiële ondersteuning. In verse 11-12 trek hy nou die konklusie by wyse van twee vrae. In die Grieks word geen antwoorde geïmpliseer nie, maar die gevolgtrekking is duidelik en logies: hy het geestelike saad onder hulle gesaai; gevolglik is dit nie te veel gevra om 'n materiële oes te maai nie. Wat meer is: Ander mense het dié soort ondersteuning ontvang wat Paulus hier vir homself opeis. As ánder mense dit dan ontvang het, hoeveel te meer het hy nie die reg nie - al het hy nooit daarvan gebruik gemaak nie.

Conzelmann (1975:155) en Fee (1988:409-10) stem saam dat die twee vrae gevolgtrekkings maak op grond van die argumente in 9:4-10. Die implikasies van albei vrae is voor die handliggend. Deur die gevolgtrekkings in die vorm van twee vrae te giet, verhoog Paulus die kommunikatiewe impak daarvan. Die impak word - volgens Lenski (1963:363) - verder verhoog deur 'n argument van die meerdere (geestelike saad) na die mindere (stoflike lewensonderhoud), asook deur die jukstaposisie van ons/julle in die oorspronklike taal (9:11). Die jukstaposisie is goed weergegee in die Afrikaanse vertaling hierbo aangehaal. Die argument waarop Lenski wys, word natuurlik omgekeer in 9:12: van die mindere (die ander) na die meerdere (ons). Deur die vrae en soorte argumente word die kern van Paulus se betoog in hoofstuk 9 oortuigend saamgevat.

Die vraagvorme in 9:11-12 behoort as vrae vertaal te word en nie as stellings herskryf te word nie, omdat hulle implikasies volkome duidelik is.

\subsubsection{Vrae wat emosie oordra}

Anders as by vraagstellings, gaan dit in hierdie hoofkategorie nie in die eerste plek om ' $n$ stelling wat gemaak word nie, maar om 'n emosie wat oorgedra word. Hierdie vrae is ook nie-egte vrae, omdat hulle nie inligting van O verwag nie, maar emosie wil oordra. Kriteria wat gebruik kan word om hierdie soort vraag te identifiseer, sluit in bondige formulering en die konteks waarbinne dit voorkom. Met hierdie vraagvorm verwag $\mathrm{M}$ emosionele instemming van $\mathrm{O}$; sy doel is om $\mathrm{O}$ by die emosie te betrek (Verster 1999:100-101).

Die hoofkategorie word verdeel in vrae wat positiewe, en dié wat negatiewe emosie oordra. 
Voorbeelde van eersgenoemde in 1 Kor 9 is die volgende:

1 Kor 9:1: Is ek nie vry nie?

Is ek nie 'n apostel nie?

Het ek nie vir Jesus, onse Here, gesien nie?

Is julle wat aan die Here behoort, nie die vrug van my werk nie?

In die voorafgaande hoofstuk (8:4-13) het Paulus dit gehad teen die sogenaamde "sterkes" in Korinte, wat hulle beroem het op hulle kennis en vryheid en so struikelblokke geword het vir hulle wat swak is. Teenoor die sterkes stel hy sy eie posisie oor die eet van vleis wat aan die afgode geoffer is: "Daarom, as ek deur wat ek eet my broer laat struikel, sal ek nooit weer vleis eet nie; ek wil nie my broer se val veroorsaak nie" (8:13). Vir die eerste keer in die hoofstuk gebruik Paulus hier die eerste persoon enkelvoud en volg dit dan op met die vier vrae in 9:1, waarvan die eerste oor sy vryheid die belangrikste is. Die rede waarom hy dit in hierdie konteks vooropstel, is om te beklemtoon dat hy (as apostel) vrywillig afstand gedoen het van sy "regte" - dié regte wat die sterkes in Korinte beskou het as ' $n$ integrale deel van die posisie en status van 'n ware apostel (Conzelmann 1975:152; Thiselton 2000:666).

Vir die doel van hierdie studie is die onverwagte en kragtige styl van die vier vrae, wat deur verskeie Skrifverklaarders (Barrett 1979:200; Thiselton 2000:666; Bratcher 1982:79; Fee 1988:394) uitgewys is, van belang. Laasgenoemde twee navorsers beskou ook die vrae as gelaai met emosie. Met die vrae jubel Paulus oor sy apostelskap. In die laaste vraag rig hy hom regstreeks tot die Korintiërs met ' $n$ ad hominem argument: hulle as gemeente in die goddelose wêreldstad Korinte, is die sterkste bewys van sy apostelskap. Hy het die gemeente gestig, en as hulle nie sy apostelskap erken nie, hef hulle hulle eie bestaan op (Conzelmann 1975:152)!

Die vraagvorme (wat vanselfsprekend positiewe antwoorde impliseer), behoort as vrae vertaal te word om die emosionele impak daarvan te verseker.

\subsubsection{Rasioneel-argumentatiewe vrae}

Dié hoofkategorie nie-egte vrae word verdeel in vraagappélle en ironiese interrogatiewe. Verskeie voorbeelde van eersgenoemde kom in hoofstuk 9 voor:

\subsubsection{Vraagappélle}

Hierdie vraagvorm word gebruik met die betekeniswaarde van 'n appél, met ander woorde die vraag is daarop gerig om die aandag van $\mathrm{O}$ te kry. Geen verbale reaksie word van $\mathrm{O}$ verwag nie, omdat $M$ self die antwoord verskaf. Die funksie van ' $n$ vraagappél is om ' $n$ nuwe argument in te lei, en word ook soms gebruik om 'n bestaande argument uit te bou aan die hand van ' $n$ logiese vraag wat na aanleiding van die argument ontstaan. In albei gevalle verskaf $M$ dan self die antwoord. Vraagappélle is nuttige instrumente om 'n saak rasioneel en argumentatief op te bou. Die intensiteit van aandag wat $\mathrm{M}$ wil trek, bepaal die wyse waarop die vraag geformuleer word (Verster 1999:65-66).

Die volgende vraagvorme is vraagappélle, met die antwoord wat Paulus self verskaf tussen hakies:

1 Kor 9:8: Is wat ek sê miskien net alledaagse waarhede (kata anthrôpon) of sê die wet dit nie ook nie?

[9:9a Want in die wet van Moses is geskrywe: Jy mag nie 'n bees waarmee jy graan dors, se bek toebind nie]

9:9b: Is dit miskien oor die beeste dat God Hom bekommer?

9:10a: Of sê Hy dit juis ter wille van ons?

[9:10b: Ja, ter wille van ons is dit geskrywe. Hy wat ploeg, moet met verwagting ploeg, en wat hy wat dors, moet dit doen met die verwagting om sy deel te ontvang]. 
Bogenoemde vrae vorm deel van Paulus se argument oor sy reg op die Korintiërs se materiële ondersteuning, waarmee hy in 9:4 begin het en in 9:12 afsluit. Die geïmpliseerde antwoorde op die vrae is ietwat problematies, maar tog duidelik. Die eerste deel van die vraag in 9:8 begin met $m \bar{e}$ en impliseer dus 'n negatiewe antwoord. Die tweede deel, wat begin met die partikel "of", impliseer egter 'n positiewe antwoord, al vorm dit grammatikaal deel van dieselfde vraag. Hierdie deel word positief beantwoord in 9:9a. Aan die einde van vers 9 het ons weer dieselfde verskynsel: die eerste deel van die vraag is gemerk deur mē en verwag 'n negatiewe antwoord, terwyl die tweede deel aan die begin van 9:10, wat ook deur mē regeer word, 'n positiewe antwoord verwag. Dit word wel so beantwoord in die res van 9:10. Die partikel mē regeer dus in albei gevalle slegs die eerste deel van die alternatief, terwyl die tweede deel ' $n$ positiewe antwoord impliseer en ook so beantwoord word.

Met die stel vrae en antwoorde gebruik Paulus ' $n$ argument kata nomon (volgens die wet) om sy reg op die Korintiërs se materiële ondersteuning te beklemtoon. Hy hét die reg - nie net kata anthrõpon nie, maar ook kata nomon. Die vraagappél in 9:8 word dus gebruik om 'n nuwe argument in te lei en word deur Paulus self beantwoord in 9:9a, terwyl die appélle in 9:9b en 9:10a daaruit voortvloei en in 9:10b beantwoord word. Die vrae is nie bedoel om antwoorde van sy lesers te kry nie, maar om hulle aandag te vra vir stellings wat hy maak in die rasionele opbou van sy argument.

In die lig van hulle funksie word aanbeveel dat die vraagvorme in 9:8-10 as vrae vertaal word, soos hierbo aangedui. Dit is nie nodig om (soos in die 1983 Afrikaanse vertaling) die eerste deel van die vraag in 9:8 as 'n stelling te herskryf nie, omdat die negatiewe antwoord wat geïmpliseer word, duidelik genoeg is, en 'n stelling die impak van die kommunikasie verskraal.

1 Kor 9:13: Weet julle nie dat dié wat tempeldiens verrig, uit die tempel lewe, en dat dié wat die altaar bedien, uit die offers hulle deel ontvang nie?

[9:14: So het die Here ook bepaal dat dié wat die evangelie verkondig, hulle lewensonderhoud hieruit moet ontvang].

In 9:13 bied Paulus nog 'n argument waarom hy reg het op die Korintiërs se materiële ondersteuning. Vir die doel gebruik hy die bekende "Weet julle nie dat ...?" vraagvorm, wat ook in 9:24 voorkom. Die vraagvorm word ingelei deur die partikel ou, wat 'n positiewe antwoord impliseer: natuurlik weet hulle dat dié wat die tempeldiens verrig, uit die tempel lewe. Dit is nie duidelik of die twee dele van die vraag sinoniem is, dit wil sê of die tempeldiens en die altaardiens identies is, en of die eerste deel in ' $n$ breër sin verstaan moet word nie. Vir die doel van die argument hier is dit egter nie belangrik nie (Conzelmann 1975:157). Die geïmpliseerde antwoord is positief: in sowel die Joodse as die heidense tempels het die priesters wat die offers gebring het, hulle deel as voedsel ontvang (Fee 1988:412).

Net só - bring Paulus sy punt tuis - het die Here self bepaal dat hulle wat die evangelie verkondig, daaruit moet lewe (9:14). Dit is die eíntlike stelling wat hy wil maak, in opvolging van sy vraag in 9:13 en in pas met sy hele betoog in 9:1-12. Die vraagvorm in 9:13 lei dus 'n nuwe argument in of voeg nog een by dié wat in 9:7 gebruik is. Dit vra aandag vir die antwoord wat die apostel self verskaf in 9:14 en kan dus as ' $n$ vraagappél beskou word. Om die positiewe antwoord wat geïmpliseer word te versterk, kan die woordjie "dan" in die vertaling ingevoeg word (Conradie et. al. 1995:416): "Weet julle dan nie dat dié wat tempeldiens verrig, uit die tempel lewe nie ...?"

1 Kor 9:18a: Wat is my loon dan?

[18b: Dit is dat ek as prediker die evangelie kosteloos verkondig en so afstand doen van my reg wat aan die verkondiging van die evangelie verbonde is].

Die konteks waarin die vraag in 9:18a gevra word, is steeds Paulus se reg (eksousia) en vryheid as apostel - dit, waaroor hy dit het vanaf 9:1. Die Korintiërs het sy weiering om van sy apostoliese 
eksousia gebruik te maak beskou as 'n bewys dat hy geen eksousia gehad het nie. Die feit is egter dat hy dit wel gehad het - soos in 9:1 beredeneer - maar dat hy nie daarvan gebruik gemaak het nie (9:15). Dit het hy gedoen ter wille van die evangelie wat hy moes verkondig, omdat die dwang hom opgelê is. Omdat dit só is, is daar vir hom geen roem daarin om die evangelie te verkondig nie (9:16).

Naas roem verwys Paulus in vers 17 na die kwessie van loon wat hom toekom. Dit lei tot die logiese vraag in 9:18a: Wat is daardie loon? Dit bestaan daarin dat hy geen loon ontvang het nie - so beantwoord hy self die vraag $(9: 18 b)$. Sy loon is dat hy geen loon ontvang het nie - ' $n$ paradoks waarop Groenewald (1967:117) en Conzelmann (1975:158) reeds gewys het en wat hulle albei as effektiewe oorreding beskou. Dit dien om Paulus se punt te beklemtoon en sy lesers tot sy standpunt te oorreed.

In die lig hiervan is die vraag in 9:18a 'n tipiese voorbeeld van 'n vraagappél, omdat dit slegs aandag vra vir die antwoord wat Paulus self verskaf. Dit is nie maar net nog 'n retoriese vraag, soos die kommentatore hierdie vraag, en al die ander vrae in 1 Korintiërs, beskryf nie. Dit is ook nie ' $n$ retoriese vraag in terme van die raamwerk wat in hierdie studie gebruik word nie, omdat dit nie ' $n$ stelling met groot intensiteit maak nie. Dit wil slegs die aandag van die lesers kry vir die antwoord wat volg en hulle so by die argument betrek.

Die antwoord in 9:18b word verder verduidelik in 9:19-23, waar Paulus uiteensit hoé volkome hy van sy eksousia afstand gedoen het. Dit strek veel verder as net sy reg op hulle materiële ondersteuning. Op die wyse het hy vry geword van alle menslike beperkinge ten einde al meer diensbaar te word aan die evangelie.

1 Kor 9:24a: Weet julle nie dat atlete wat aan 'n wedloop deelneem, wel almal hardloop,

maar dat net een die prys ontvang nie?

[9:24b: Hardloop dan só dat julle die prys kan wen.

9:25: Almal wat aan 'n wedstryd deelneem, ontsê hulleself allerlei dinge. Hulle doen dit om

'n verganklike oorwinnaarskroon te verkry, maar ons 'n onverganklike].

In die voorafgaande gedeelte (9:19-23) het Paulus homself beskryf as iemand wat vry geword het ten einde die evangelie voluit te kan verkondig. In 9:24 verwissel hy die eerste persoon enkelvoud met die tweede persoon meervoud as hy die Korintiërs direk konfronteer met nog ' $n$ "Weet julle nie ..." vraagvorm, wat 'n positiewe antwoord impliseer. Afgesien van die persoonswisseling, lei Paulus ook ' $n$ nuwe tema in met die beeld van ' $n$ atleet op die atletiekbaan. Die beeld is ontleen aan die Isthmiese spele, wat elke twee jaar gehou is en waarmee die Korintiërs goed bekend was. Die vraag in 9:24a word onmiddellik opgevolg met ' $n$ aansporing om die Christelike wedloop op dieselfde wyse te hardloop as die atlete wat aan die spele deelneem: met volle inspanning ten einde die prys te wen. In 9:25 brei Paulus uit op die soort prys wat behaal word, voordat hy in 9:26-27 weer na homself in die eerste persoon enkelvoud terugkeer.

Dit is duidelik dat die vraag in 9:24a 'n vraagappél is, omdat dit 'n nuwe tema inlei en onmiddellik gevolg word deur ' $n$ antwoord van Paulus self. As vraagappél vra dit die aandag van die lesers vir die eíntlike stelling (aansporing) wat hy self wil maak. Die aansporing om so te hardloop dat hulle die prys kan behaal is die kern van alles wat Paulus in die paragraaf (9:2427) wil kommunikeer (Fee 1988:436). Dit is die tertium comparationis tussen die atleet en die Christen gelowige. In vers 25 word die prys nader beskryf in terme van 'n verganklike en ' $n$ onverganklike oorwinnaarskroon. Dit is 'n tipiese argument van die mindere (verganklike) na die meerdere (onverganklike): as atlete hulleself só inspan om 'n aardse kroon te verwerf, hoeveel meer moet gelowiges opoffer om die hemelse kroon te ontvang (Lenski 1963:383).

Soos by 9:13 hierbo behoort die vraag behou te word en die positiewe implikasie daarvan 
versterk te word deur "dan" in te voeg: "Weet julle dan nie dat atlete wat aan 'n wedloop deelneem, wel almal hardloop, maar dat net een die prys ontvang nie?"

\section{KONKLUSIE}

Die doel van hierdie studie was om die nie-egte vrae in 1 Kor 9 sistematies te ondersoek aan die hand van 'n model, wat gebaseer is op die taalhandelingsteorie en reeds met goeie gevolg op die brief aan die Romeine toegepas is. Die model het ook hier bruikbare resultate gelewer. Van die kategorieë nie-egte vrae wat Verster onderskei, is vier in 1 Kor 9 geïdentifiseer. Op die wyse is hulle nie maar gelyk gestel aan retoriese vrae nie, maar is hulle verder verfyn en hulle funksies aan die hand van ' $n$ erkende taalteorie beskryf.

Deur die verskillende soorte nie-egte vrae te onderskei is ook probeer om 'n bydrae tot die eksegese en vertaling van die betrokke tekste te maak. Die gevolgtrekking is dat Paulus die nieegte vrae in 1 Korintiërs 9 effektief gebruik om sy apostelskap te verdedig en die Korintiërs tot sy standpunt te oorreed.

\section{BIBLIOGRAFIE}

Argyle, AW 1965. An Introductory Grammar of New Testament Greek. New York: Cornell University. Barrett, CK 1979. A commentary on the first epistle to the Corinthians. London: Black.

Blass F, Debrunner, A \& Funk, RW 1967. A Greek Grammar of the New Testament and other Early Christian Literature. Chicago: University Press.

Bratcher, RG 1982. A Translator's Guide to Paul's First Letter to the Corinthians. Helps for Translators Series. New York: UBS.

Burton, EdeW 1955. Syntax of the Moods and Tenses in New Testament Greek. Edinburgh: T\&T Clark. Chamberlain, WD 1957. An Exegetical Grammar of the Greek New Testament. New York: MacMillan.

Conradie et.al. 1995. Grieks met Begrip. 'n Inleidende Grammatika, toegespits op die Griekse Nuwe Testament. (Die Werkgroep vir Griekse Onderrig). PU vir CHO: Departement Sentrale Publikasies. (Vyfde hersiene uitgawe).

Conzelmann, H 1975. 1 Corinthians: A Commentary on the First Epistle to the Corinthians. (Trans.) Hermeneia. Philadelphia: Fortress.

Fee, GD 1988. The First Epistle to the Corinthians. Grand Rapids: Eerdmans. (Reprint).

Goetchius, EvN 1965. The Language of the New Testament. New York: Scribner.

Groenewald, EP 1967. Die Eerste Brief aan die Korintiërs. Kaapstad - Pretoria: NG Kerk Uitgewers.

Grosheide, FW 1957. De eerste brief aan de kerk te Korinthe. Commentaar op het Nieuwe Testament. Kampen: N.V. Uitgeversmaatschappij J.H.Kok.

Lenski, RCH 1963. The interpretation of St. Paul's first and second epistles to the Corinthians. Minneapolis: Augsburg.

Moulton, JH 1908. A Grammar of New Testament Greek. Edinburgh: T \&T Clark.

Nunn, HPV 1973. A Short Syntax of New Testament Greek. Cambridge: Cambridge University Press.

Robertson, AT 1919. A Grammar of the Greek New Testament in the Light of Historical Research. New York: Hodder \& Stoughton.

Thiselton, AC 2000. The First Epistle to the Corinthians. A Commentary on the Greek Text. NIGTC. Grand Rapids, Michigan, Cambridge: WB Eerdmans Publishing House.

Turner, N 1963. A Grammar of New Testament Greek. Edinburgh: T\&T Clark.

Verster, P 1999. Nie-egte vrae in die Romeinebrief: ' $n$ Taalhandelingsperspektief. Bloemfontein: UV. (Ongepubliseerde MA verhandeling.)

Van Jaarsveld, GJ (Red.) 1987. Wat bedoel jy? Pretoria: Serva.

\section{KEY WORDS}

1 Corinthians 9

Speech Act Theory 
Rhetorical questions

Non-real questions

TREFWOORDE

1 Korintiërs 9

Taalhandelingsteorie

Retoriese vrae

Nie-egte vrae 